\title{
Pengaruh iradiasi sinar gamma terhadap fertilitas Sternochetus frigidus (Fabricius) (Coleoptera: Curculionidae) pada mangga kuini
}

\author{
Effect of gamma ray irradiation on fertility of Sternochetus frigidus \\ (Fabricius) (Coleoptera: Curculionidae) in mangoes cv kuini \\ Ade Syahputra $^{1 *}$, Mustopha Ahad ${ }^{1}$, Abdurakhman ${ }^{1}$, Joni Hidayat ${ }^{1}$, \\ Djoko Prijono $^{2}$, Indah Arastuti Nasution ${ }^{3}$ \\ ${ }^{1}$ Balai Uji Terap Teknik dan Metode Karantina Pertanian \\ Jalan Raya Kp. Utan-Setu, Desa Mekar Wangi, Kec. Cikarang Barat, Bekasi 17320 \\ ${ }^{2}$ Departemen Proteksi Tanaman, Fakultas Pertanian, Institut Pertanian Bogor \\ Jalan Kamper, Kampus IPB Dramaga, Bogor 16680 \\ ${ }^{3}$ Pusat Aplikasi Isotop dan Radiasi, Badan Tenaga Nuklir Nasional (PAIR-BATAN) \\ Jalan Lebak Bulus Raya, No. 49, Kelurahan Pasar Jum'at, Kec. Pondok Indah, Jakarta Selatan 12440
}

(diterima Februari 2019, disetujui Maret 2020)

\begin{abstract}
ABSTRAK
Salah satu tindakan perlakuan karantina yang diakui oleh lembaga internasional dan aman bagi konsumen adalah penggunaan iradiasi sinar gamma pada dosis yang direkomendasikan. Tujuan penelitian ini adalah menguji keefektifan dosis generik iradiasi sinar gamma $\left[{ }^{60} \mathrm{Co}\right]$ untuk mensterilisasi kumbang Sternochetus frigidus (Fabricius) pada buah mangga kuini (Mangifera odorata Griff). Sebanyak $300 \mathrm{~kg}$ buah kuini yang dipastikan terinfestasi S. frigidus diambil dari Sumatera Barat dan Lampung. Perlakuan iradiasi sinar gamma pada dosis 50, 100, 150, 200, 300, dan 400 Gy masing-masing dilakukan terhadap 6-8 buah kuini per kotak dan diulang tiga kali. Perlakuan iradiasi dilakukan dalam dua percobaan. Percobaan pertama pada bulan April untuk buah kuini asal Sumatera Barat dan yang kedua pada bulan Mei untuk buah yang berasal dari Lampung. Perlakuan iradiasi sinar gamma menurunkan kemampuan makan, hidup normal, produksi telur, dan meningkatkan kematian imago. Iradiasi sinar gamma memengaruhi perkembangan pupa dan imago. Pengaruh iradiasi sinar gamma terhadap hidup normal imago lebih tinggi ditunjukkan pada percobaan pertama dengan waktu pengamatan pada minggu ke delapan dibandingkan dengan pengamatan percobaan kedua dengan waktu pengamatan pada minggu ke empat. Pupa yang diradiasi pada dosis 100 Gy masih mampu menjadi imago, namun tidak mampu menghasilkan telur. Imago yang diiradiasi pada 150 Gy masih mampu bertelur dengan rataan 6 butir (percobaan pertama) dan 2,3 butir (percobaan kedua), namun telur yang dihasilkan tidak mampu berkembang menjadi larva. Imago yang diradiasi pada dosis 200 Gy tidak mampu menghasilkan telur untuk kedua percobaan.
\end{abstract}

Kata kunci: imago, iradiasi sinar gamma, Mangifera odorata, sterilitas, Sternochetus frigidus

\begin{abstract}
One of the recognized and safe quarantine treatments for consumers is the use of gamma-ray irradiation $\left[{ }^{60} \mathrm{Co}\right]$ at a recommended dose requested by the destination country or international agency. The purpose of this study was to test the effectiveness of a generic dose of gamma ray irradiation for sterilizing mango pulp weevil Sternochetus frigidus (Fabricius) on mangoes cv kuini (Mangifera odorata). A total of $300 \mathrm{~kg}$ pulp-weevil-infested mango fruits was collected from West Sumatra and
\end{abstract}

\footnotetext{
*Penulis korespondensi: Ade Syahputra. Balai Uji Terap Teknik dan Metode Karantina Pertanian, Jalan Raya Kp. Utan-Setu, Desa Mekar Wangi, Kec. Cikarang Barat, Kab. Bekasi, Jawa Barat 17320, Tel/Faks: 021-82618923, Email: ade@buttmkp.org
} 
Lampung. First experiment was conducted on April to irradiate fruits collected from West Sumatera and second experiment was on May to irradiate fruits collected from Lampung. In each treatment, a box containing 6-8 M. odorata fruits was irradiated with gamma-ray at doses of 50, 100, 150, 200, 300, 400 Gy with three replications. The treatment of gamma-ray irradiation could reduce feeding activity, normal life of insect, egg production and increase mortality of adults. The results of the first and second experiments showed that gamma ray irradiation was able to influence the development of pupae and adults. There were differences in the normal development of adults in the two experiments. The number of normal development of adults on first experiment was higher than on the second experiment. The irradiated pupae at dose of 100 Gy successfully develop to be adults but the adults are unable to produce eggs. Adults irradiated at $150 \mathrm{~Gy}$ are still able to lay eggs with the average of 6 eggs (first experiment) and 2,3 larvae (experiment II), 150 Gy average 6 eggs and do not hatch. Doses at 200 Gy no eggs were produced.

Key words: adults, gamma ray irradiation, Mangifera odorata, sterility, Sternochetus frigidus

\section{PENDAHULUAN}

Data Badan Pusat Statistik tahun 2015 dan 2016 menunjukkan adanya penurunan kontribusi nilai ekspor buah mangga dari 5\% menjadi $2 \%$ dari nilai total ekspor buah yang sebesar 36,56 juta dollar US pada tahun 2016. Menurunnya nilai ekspor mangga seiring dengan menurunnya kontribusi produksi dari $12 \%$ (peringkat ketiga) menjadi $1 \%$ (peringkat keenam) setelah manggis (59\%), plaintain berupa bagian produk hasil olahan pisang baik kering maupun basah (16\%), buah pisang $(15 \%)$, nenas $(3 \%)$, dan salak $(2 \%)$ dari total 12 juta ton produksi buah di Indonesia (BPS 2016). Saat ini, sebagian besar mangga yang diekspor berjenis harum manis dan gedong gincu. Salah satu penyebab rendahnya ekspor buah mangga dibandingkan dengan buah lain disebabkan adanya infestasi organisme pengganggu tumbuhan karantina (OPTK) bagi negara tujuan (Ditjen Horti 2016).

Saat ini, ekspor buah mangga ke negara maju di antaranya Jepang, Australia, dan Amerika Serikat terhambat oleh keberadaan OPTK. Salah satu tindakan perlakuan karantina yang diakui dan aman bagi konsumen adalah iradiasi sinar gamma dengan dosis yang direkomendasikan oleh negara tujuan atau lembaga International Atomic Energy Agency (IAEA 2002; Hallman 2016). Konsumen internasional, khususnya dari Jepang, Eropa, dan Amerika Serikat, menginginkan jaminan kualitas dan keamanan mangga, termasuk bebas lalat buah dan penggerek buah, serta residu pestisida (Miyauchi \& Perry 1999). Australia membuka akses pasar bagi buah mangga segar asal Indonesia dengan persyaratan harus diberi perlakuan iradiasi sinar gamma pada dosis 400 Gy, untuk mengeradikasi lalat buah, kutu putih, penggerek biji mangga, dan penggerek buah mangga (DAWR 2015).

Tujuan perlakuan iradiasi dengan sinar gamma adalah untuk membunuh, menginaktivasi, mensterilisasi (memandulkan) atau menghambat perkembangan serangga. Hal ini sesuai dengan ketentuan perdagangan internasional dalam tindakan fitosanitari yang mana perdagangan harus bebas dari hama karantina tumbuhan (IPPC 2009). Dosis generik yang direkomendasikan dalam tindakan karantina dengan sasaran serangga sekitar 100-400 Gy dengan tujuan agar serangga yang diiradiasi menjadi mandul (ICGI 1986).

Salah satu upaya yang dapat dilakukan untuk meningkatkan kualitas ekspor buah mangga adalah melalui pengembangan teknik perlakuan karantina untuk membebaskan atau mengeradikasi serangga penggerek buah mangga dengan teknik iradiasi sinar gamma Co-60. Tujuan penelitian ini adalah menguji keefektifan dosis generik iradiasi sinar gamma terhadap Sternochetus frigidus (Fabricius) pada buah kuini Mangifera odorata Griff. Hasil penelitian ini diharapkan dapat digunakan sebagai bahan pertimbangan Badan Karantina Pertanian dalam penyusunan petunjuk teknis perlakuan dengan menggunakan iradiasi sinar gamma terhadap buah mangga untuk keperluan ekspor.

\section{BAHAN DAN METODE}

\section{Tempat dan waktu}

Penelitian dilaksanakan di Laboratorium Entomologi, Balai Uji Terap Teknik dan Metode 
Karantina Pertanian (BUTTMKP) Bekasi serta Pusat Aplikasi Isotop dan Radiasi Badan Tenaga Nuklir Nasional (PAIR-BATAN) Jakarta dari bulan Maret sampai September 2017.

Pengumpulan buah kuini terinfestasi $S$. frigidus

Penggerek buah $S$. frigidus tidak dapat dikembangbiakkan pada makanan buatan (artificial diet) sehingga harus diperoleh langsung dari inangnya, seperti pada buah mangga (De Jesus \& Gabo 2000). Sampel buah kuini yang terinfestasi S. frigidus diambil dari Sumatera karena serangga tersebut paling banyak ditemukan pada buah kuini, selain buah bacang yang banyak terdapat di lokasi tersebut. Keberadaan serangga di dalam buah tidak menunjukkan gejala luar yang khas sehingga untuk memastikan keberadaan $S$. frigidus, sebanyak 3 buah kuini dipetik dari pohon lalu dibongkar dan diamati keberadaan serangganya.

Pengumpulan buah kuini terinfestasi secara alami dari Sumatera Barat dan Lampung dilakukan dengan mengumpulkan buah yang masih terdapat di pohon kebun petani. Pengambilan buah dilakukan dua kali, pertama dilakukan pada bulan April 2017 di Sumatera Barat dan pengambilan kedua dilakukan pada bulan Mei 2017 di Lampung.

Buah kuini yang berumur sekitar 95 sampai 115 hari setelah pembungaan dipetik dari pohon yang berumur 10-15 tahun. Penentuan umur buah kuini dilakukan dengan melibatkan petani di sekitar kebun buah kuini. Umur buah yang dipanen mengikuti data siklus hidup $S$. frigidus yang dilaporkan De Jesus \& Gabo (2000). Selanjutnya, buah kuini dimasukkan ke dalam tiga kotak peti kayu, masing-masing sebanyak $50 \mathrm{~kg}$, yang selanjutnya dikirim dengan menggunakan transportasi darat.

Identifikasi spesies dan jenis kelamin $S$. frigidus Identifikasi spesies $S$. frigidus dilakukan dengan membedah bagian genitalia serangga.

Bagian dorsal dibelah lalu potongan bagian kelamin dicuci dengan larutan $\mathrm{KOH} 3 \%$ melalui perendaman selama tiga menit di dalam cawan sirakus. Selanjutnya, bagian aedeagus spesimen tersebut dibersihkan dengan kuas halus. Pengamatan aedeagus dilakukan di bawah mikroskop stereo. Apabila aedeagus pada bagian ujung apical sclerite terpisah, individu tersebut merupakan S. mangiferae, tetapi apabila bagian tersebut tumpang tindih, individu tersebut merupakan S. frigidus (Poonchaisri \& Chaowalit 2008) (Gambar 1).

\section{Penentuan jenis kelamin serangga dewasa}

Pengamatan jenis kelamin secara morfologi dilakukan dengan mengamati struktur bagian ventral abdomen imago di bawah mikroskop stereo (Boeco). Apabila bagian ventral abdomen datar, individu tersebut jantan (Gambar 2). Setelah diketahui jenis kelaminnya, imago dikumpulkan dan dipisahkan sesuai jenis kelaminnya, yang selanjutnya serangga tersebut dipasangkan untuk dilakukan proses kawin dan peneluran.

\section{Pengukuran dosis radiasi}

Dosimetri atau pengukuran dosis radiasi ini menggunakan dosimeter radiochromic film (1$\mathrm{cm} 2$, Gafchromic HD-810, ISP Technologies, Inc., Wayne, New Jersey) yang telah tersedia di Iradiator Panorama Serbaguna (Irpasena), PAIRBATAN. Pengukuran dilakukan di dosis maksimum (Dmax) dan minimum (Dmin) berdasarkan

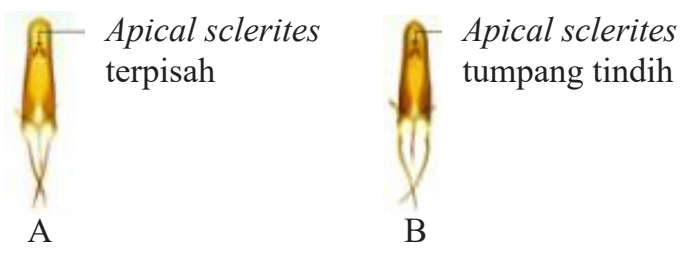

Gambar 1. Perbedaan aedeagus jantan dua spesies Sternochetus. A: S. mangiferae; B: $S$. frigidus (Poonchaisri \& Chaowalit 2008).

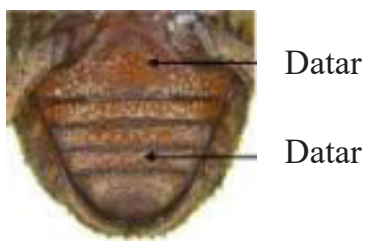

A

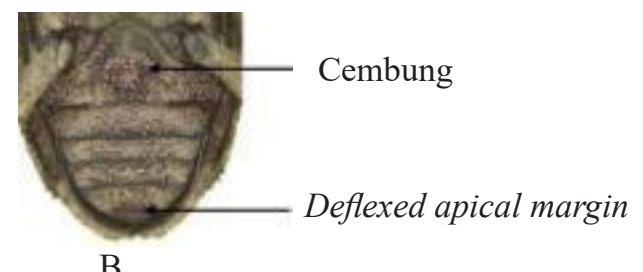

B

Gambar 2. Perbedaan ciri serangga jantan dan betina Sternochetus frigidus pada bagian ventral abdomen A: jantan; B: betina (Poonchaisri \& Chaowalit 2008). 
iradiasi yang diperoleh. Media kemasan yang digunakan untuk iradiasi berupa kotak yang terlebih dahulu dilakukan dosimetri sehingga pada saat perlakuan iradiasi tidak lagi dilakukan dosimetri.

\section{Perlakuan iradiasi sinar gamma}

Perlakuan iradiasi sinar gamma dilakukan di BATAN, Jakarta dalam dua kali percobaan. Percobaan pertama dilakukan pada bulan April untuk buah kuini yang berasal dari Sumatera Barat dan percobaan kedua dilakukan pada bulan Mei untuk buah yang berasal dari Lampung. Buah kuini yang akan diiradiasi dimasukkan ke dalam kotak kemasan (dari kertas kardus) dengan ukuran $29 \mathrm{~cm}$ x $21 \mathrm{~cm}$ x $10 \mathrm{~cm}$, densitas $0,25 \mathrm{~g} / \mathrm{cm}^{3}$. Buah diberi perlakuan iradiasi sinar gamma dengan dosis 50 , 150, 100, 200, 300, dan 400 Gy, serta kontrol. Setiap perlakuan dilakukan 3 ulangan, dengan setiap ulangan terdiri atas 4 kotak yang masingmasing berisi 6-8 buah. Kotak ditempatkan di sekitar sumber iradiasi. Sinar gamma yang digunakan memiliki panjang gelombang sebesar $3 \times 10^{-9} \mathrm{~cm}$ sampai $3 \times 10^{-11} \mathrm{~cm}$, dan energi yang dihasilkan sebesar 1,17-1,33 MeV. Aktifitas Cobalt-60 hingga April 2017 sebesar 11.242,66 Ci dengan laju dosis $1000 \mathrm{~Gy} / \mathrm{jam}$. Adapun waktu laju iradiasi tiap dosis berbeda-beda (Tabel 1).

\section{Pemeliharaan stadia larva dan pupa, dan imago serangga $S$. frigidus}

Setelah perlakuan iradiasi, buah kuini yang berada di dalam kotak dibawa ke laboratorium BUTTMKP, lalu disimpan pada suhu ruang selama satu hari. Kemudian, seluruh buah kuini dibongkar, diambil lalu dihitung jumlah seluruh fase serangga yang meliputi larva, pupa, dan imago yang ada di dalam daging buah. Pemeliharaan fase serangga dari larva (instar 1 sampai 5) ke pupa, dari pupa ke imago dilakukan di dalam stoples. (diameter $12 \mathrm{~cm}$ dan tinggi $13 \mathrm{~cm}$ ). Setiap stoples masingmasing berisi satu instar. Jumlah stoples tiap instar sebanyak 3 stoples dalam satu perlakuan. Stadia larva dipelihara selama 20 hari dan pupa selama 7 hari (Jesus \& Gabo 2000). Untuk pemeliharaan imago dari hasil perkembangan pupa dimasukkan ke dalam tiga stoples baru (diameter $12 \mathrm{~cm}$, tinggi $13 \mathrm{~cm}$ ), masing-masing berisi 1-3 pasang imago tiap perlakuan, yang sudah dialasi dengan dua lembar kertas tisu untuk dipelihara selama 4-5 bulan pada suhu $27^{\circ} \mathrm{C}$. Imago tersebut diberi pakan setiap hari dengan satu potongan daging buah kuini yang berukuran $1,5 \mathrm{~cm}$ x 1,5 $\mathrm{cm}$ x 1,5 cm berbentuk balok. Setelah 30 hari, serangga diamati di bawah mikroskop stereo untuk mengamati kemungkinan adanya peneluran. Pengamatan dilakukan hingga tidak ada lagi aktivitas peneluran atau serangga mati (De Jesus 2008).

Tabel 1. Laju waktu dan dosis iradiasi sinar gamma pada buah kuini

\begin{tabular}{|c|c|c|c|c|}
\hline \multirow{2}{*}{ Dosis (Gy) } & \multirow{2}{*}{$\begin{array}{l}\text { Lama } \\
\text { iradiasi }\end{array}$} & \multicolumn{3}{|c|}{ Faktor keseragaman dosis Gy $(\mathrm{Dmax} / \mathrm{Dmin})=1,2$} \\
\hline & & Dosis min & Dosis max & Dosis rata-rata \\
\hline \multicolumn{5}{|c|}{ Percobaan I } \\
\hline Kontrol & - & - & - & - \\
\hline 50 & $3 \mathrm{mnt}, 12 \mathrm{dtk}$ & 49,829 & 60,343 & 55,086 \\
\hline 100 & $6 \mathrm{mnt}, 24 \mathrm{dtk}$ & 99,657 & 120,686 & 110,172 \\
\hline 150 & $9 \mathrm{mnt}, 36 \mathrm{dtk}$ & 124,380 & 175,000 & 149,690 \\
\hline 200 & $12 \mathrm{mnt}, 50 \mathrm{dtk}$ & 199,781 & 241,686 & 220,733 \\
\hline 300 & $19 \mathrm{mnt}, 16 \mathrm{dtk}$ & 300,529 & 363,943 & 332,238 \\
\hline 400 & $25 \mathrm{mnt}, 42 \mathrm{dtk}$ & 400,186 & 484,629 & 442,408 \\
\hline \multicolumn{5}{|c|}{ Percobaan II } \\
\hline Kontrol & - & - & - & - \\
\hline 50 & $3 \mathrm{mnt}, 12 \mathrm{dtk}$ & 49,287 & 59,68 & 54,487 \\
\hline 100 & $6 \mathrm{mnt}, 24 \mathrm{dtk}$ & 98,574 & 119,374 & 108,970 \\
\hline 150 & $9 \mathrm{mnt}, 36 \mathrm{dtk}$ & 123.030 & 173,100 & 48,060 \\
\hline 200 & $12 \mathrm{mnt}, 50 \mathrm{dtk}$ & 197,609 & 239,059 & 218,334 \\
\hline 300 & $19 \mathrm{mnt}, 16 \mathrm{dtk}$ & 297,262 & 359,987 & 328,627 \\
\hline 400 & $25 \mathrm{mnt}, 42 \mathrm{dtk}$ & 395,836 & 479,361 & 437,599 \\
\hline
\end{tabular}

mnt: menit; dtk: detik. 


\section{Pengamatan}

Peubah pengamatan hasil iradiasi terhadap serangga meliputi perkembangan jumlah larva yang berhasil menjadi pupa; jumlah pupa yang berhasil menjadi imago; dan imago, meliputi jumlah gigitan pada pakan, abnormalitas imago yang masih hidup, yaitu adanya getaran pada bagian antena dan kaki serta kematian imago. Selanjutnya, kemampuan imago menghasilkan sejumlah telur dan perkembangan telur menjadi larva instar satu.

Pengamatan perkembangan larva dan pupa dimulai saat setelah buah dibongkar dan disimpan di dalam stoples plastik. Pengamatan jumlah gigitan imago pada pakan dihitung melalui jumlah lubang bekas gigitan pada tiap potongan pakan berupa daging buah mangga. Pengamatan abnormalitas dan jumlah gigitan pakan dilakukan bersamaan, yaitu setiap hari selama 3 hari berturutturut pada minggu ke-8 untuk percobaan pertama dan pada minggu ke-4 untuk percobaan kedua. Penghitungan kematian imago dilakukan pada bulan ketiga, sementara itu penghitungan jumlah telur dilakukan satu bulan setelah pembongkaran buah untuk kedua percobaan.

Pengamatan jumlah telur dilakukan satu bulan untuk fase serangga dewasa dan 37 hari untuk fase pupa setelah terpapar radiasi sinar gamma, sedangkan untuk fase larva tidak dilakukan karena larva tidak dapat berkembang saat dikeluarkan dari buah. Pengamatan telur dilakukan setiap hari di bawah mikroskop stereo. Telur serangga diletakkan di atas kertas tisu atau pakan secara tunggal dan dipindahkan dari stoples ke cawan petri yang sudah dialasi kain hitam yang dilembapkan dengan air. Telur yang sudah menetas menjadi larva dihitung dan dipindahkan ke cawan petri baru. Pengamatan larva instar kesatu dilakukan setiap hari dimulai hari kelima hingga ketujuh setelah peneluran. Percobaan disusun dalam rancangan acak lengkap dengan tujuh dosis perlakuan dan tiga ulangan. Tiap ulangan berisi 10 pasang imago dalam satu stoples (volume $226,08 \mathrm{~cm}^{3}$ ).

\section{Analisis data}

Data diolah dengan sidik ragam untuk menganalisis pengaruh iradiasi terhadap sterilitas imago, dilanjutkan dengan uji Tukey menggunakan perangkat lunak Minitab 17 dengan tingkat kepercayaan $95 \%$.

\section{HASIL}

Perbandingan jumlah fase serangga dari kedua percobaan menunjukkan adanya perbedaan, jumlah larva di percobaan kedua lebih sedikit dibandingkan dengan percobaan pertama. Begitu juga jumlah imago di percobaan pertama lebih sedikit dibandingkan dengan percobaan kedua. Rata-rata jumlah serangga tiap buah di tiap perlakuan 2 sampai 3 individu/buah (Tabel 2).

Tabel 2. Rata-rata jumlah serangga dalam buah kuini tiap perlakuan dosis

\begin{tabular}{|c|c|c|c|c|c|}
\hline \multirow{2}{*}{ Dosis (Gy) } & \multirow{2}{*}{ Jumlah buah } & \multicolumn{3}{|c|}{ Jumlah (individu) } & \multirow{2}{*}{ Rata-rata/buah } \\
\hline & & Larva & Pupa & Imago & \\
\hline \multicolumn{6}{|c|}{ Percobaan I } \\
\hline Kontrol & 104 & 178 & 71 & 94 & 3,2 \\
\hline 50 & 104 & 103 & 90 & 106 & 2,8 \\
\hline 100 & 104 & 85 & 96 & 89 & 2,6 \\
\hline 150 & 104 & 94 & 94 & 123 & 3 \\
\hline 200 & 104 & 94 & 56 & 104 & 2,4 \\
\hline 300 & 104 & 168 & 67 & 123 & 3,4 \\
\hline 400 & 96 & 133 & 85 & 90 & 3,2 \\
\hline \multicolumn{6}{|c|}{ Percobaan II } \\
\hline Kontrol & 72 & 36 & 46 & 168 & 3,4 \\
\hline 50 & 72 & 39 & 53 & 99 & 2,6 \\
\hline 100 & 72 & 38 & 55 & 127 & 3 \\
\hline 150 & 72 & 44 & 50 & 122 & 3 \\
\hline 200 & 72 & 24 & 46 & 114 & 2.5 \\
\hline 300 & 72 & 33 & 52 & 116 & 2.8 \\
\hline 400 & 52 & 54 & 40 & 112 & 3.9 \\
\hline
\end{tabular}


Identifikasi spesies dan jenis kelamin $S$. frigidus

Hasil identifikasi memastikan bahwa serangga yang diperoleh merupakan S. frigidus. Hal ini ditunjukkan adanya apical sclerite yang tumpang tindih pada bagian aedeagus jantan (Gambar 3C).

Perbedaan jenis kelamin antara jantan dan betina dapat dilihat pada struktur tubuh bagian ventral abdomen (Gambar 3A dan 3B). Serangga jantan menunjukkan bagian ventral abdomen yang datar, sedangkan pada serangga betina menunjukkan cembung disertai ujung abdomen yang lebih menonjol dibandingkan dengan serangga jantan.

\section{Pengaruh iradiasi sinar gamma terhadap perkembangan larva dan pupa}

Fase larva yang terpapar iradiasi maupun yang tidak diiradiasi tidak mampu berkembang menjadi pupa di luar buah kuini sehingga data perkembangan larva tidak dapat diperoleh. Sementara itu, pupa yang terpapar sinar gamma mampu berkembang menjadi imago pada seluruh dosis perlakuan baik yang menjadi imago normal maupun tidak normal.

Pengamatan terhadap perkembangan serangga dari fase pupa ke imago selama dua minggu menunjukkan adanya perbedaan jumlah pada kondisi hidup normal dan tidak normal. Imago yang dihasilkan dari tahap pupa menunjukkan adanya ketidaknormalan pada bagian sayap elitra dan membran, yang seharusnya sayap membran berada di dalam elitra yang tertutup rapat (Gambar 4). Rataan jumlah imago hidup normal menunjukkan tidak berbeda nyata $(\mathrm{F}=2,12, \mathrm{df}=6 ; \mathrm{P}=0,071)$ di percobaan kedua, namun terdapat perbedaan di percobaan pertama walaupun jumlahnya sedikit dibandingkan pada percobaan kedua. Begitu juga rataan jumlah imago hidup tidak normal pada kedua percobaan tidak berbeda nyata $(\mathrm{F}=2,23$, df $=6, \mathrm{P}=0,099)$ tiap perlakuan radiasi gamma dan kontrol, yaitu mulai dari 1 sampai 5 individu fase imago.

Imago dari perkembangan fase pupa tidak dihasilkan telur pada kontrol percobaan pertama, sedangkan percobaan kedua terdapat rata-rata 33 butir telur pada kontrol dan 7 butir telur di dosis 50 Gy. Untuk kemunculan larva dari telur pada fase pupa hanya ditemui pada percobaan kedua, yaitu rata-rata 8 individu untuk kontrol dan 1 individu untuk 50 Gy (Tabel 3).

\section{Pengaruh iradiasi sinar gamma terhadap kondisi hidup imago}

Perlakuan iradiasi sinar gamma memengaruhi perkembangan pupa menjadi imago, yaitu

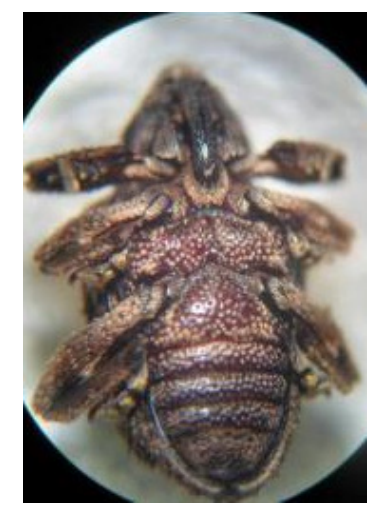

A

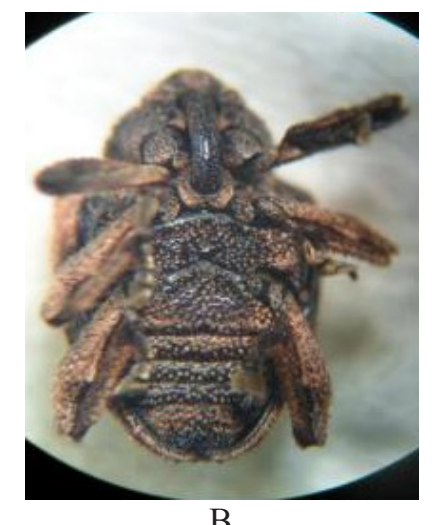

B

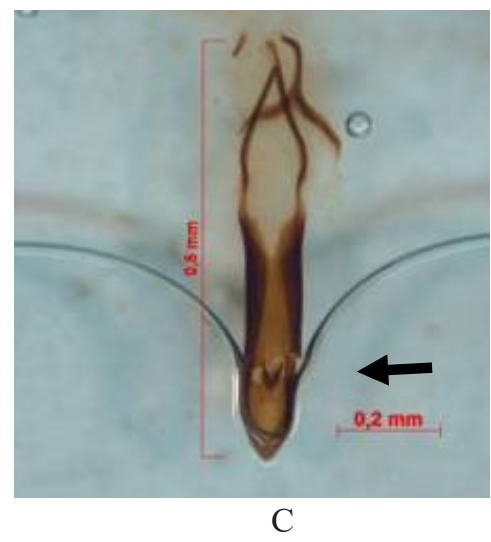

apical sclerites tumpang tindih

Gambar 3. Sternochetus frigidus. A: betina; B: jantan; C: aedeagus jantan.
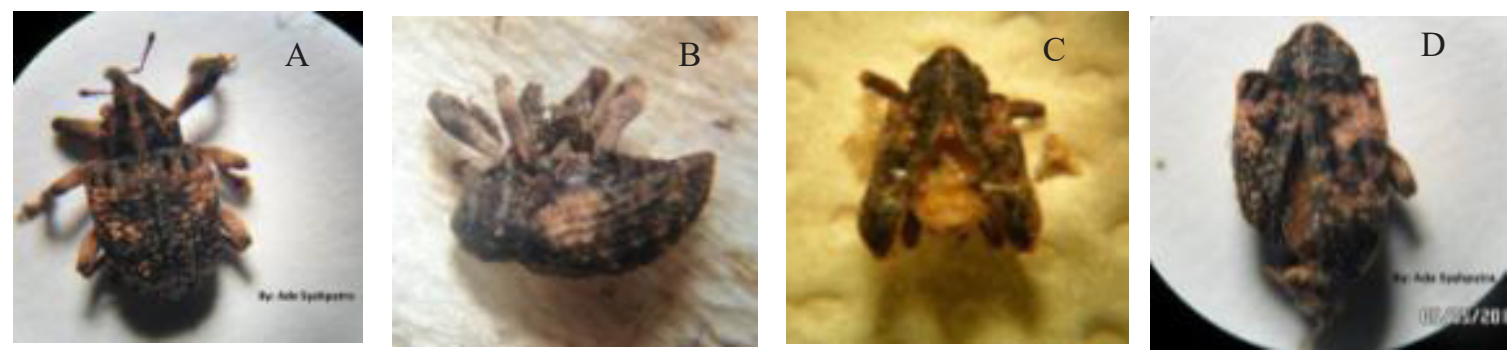

Gambar 4. Ketidaknormalan kumbang Sternochetus frigidus yang terkena iradiasi A: serangga S. frigidus kondisi hidup normal; B: mati normal; C: hidup tidak normal; D: mati tidak normal. 
menyebabkan terjadinya perkembangan sayap membran dan elitranya yang abnormal. Elitra serangga baik yang hidup maupun yang mati menunjukkan kondisi yang tidak normal (Gambar 4).

Imago S. frigidus yang mendapat perlakuan iradiasi sinar gamma menunjukkan perbedaan aktivitas makan (ditunjukkan oleh jumlah gigitan pada pakan), abnormalitas, dan kematian serangga dibandingkan dengan kontrol (tanpa perlakuan iradiasi). Secara umum, jumlah gigitan pada buah kuini semakin menurun dengan meningkatnya dosis iradiasi pada rentang walaupun terjadi sedikit fluktuatif terutama pada percobaan kedua (Tabel 4).

Gejala abnormalitas imago akibat perlakuan iradiasi sinar gamma berupa gemetar pada bagian tungkai maupun antena yang terlihat pada imago 25 hari setelah perlakuan. Respons gemetar akibat iradiasi sinar gamma meningkat jika dosis yang diberikan semakin tinggi (Tabel 4). Persentase serangga yang hidup normal pada bulan pertama menurun pada perlakuan iradiasi pada dosis yang lebih tinggi. Penurunan jumlah serangga normal dimulai dari dosis 50 Gy pada percobaan kedua, sedangkan percobaan pertama dimulai pada dosis 100 Gy. Pengaruh tersebut tampak lebih nyata pada percobaan pertama, yaitu iradiasi pada dosis
200-400 Gy menurunkan persentase serangga hidup normal secara nyata (Tabel 4).

Persentase kematian imago pada bulan ke-3 meningkat dengan semakin meningkatnya dosis iradiasi. Persentase kematian imago pada percobaan pertama dengan dosis iradiasi $100-400$ Gy berbeda secara nyata $(F=27,53, d f=6 ; P=0,000)$ daripada kontrol, sementara pada percobaan kedua berbeda nyata dengan kontrol terjadi pada dosis 200-400 Gy (Tabel 4).

\section{Pengaruh iradiasi sinar gamma terhadap sterilitas serangga imago}

Waktu awal peneluran $S$. frigidus yang diiradiasi lebih lama dibandingkan dengan $S$. frigidus yang tidak diperlakukan (kontrol) pada kedua percobaan. Dengan demikian, perlakuan iradiasi memengaruhi waktu awal peneluran dari serangga S. frigidus (Gambar 5). Disamping itu, dosis iradiasi berpengaruh terhadap kemampuan imago betina $S$. frigidus untuk menghasilkan telur. S. frigidus masih mampu bertelur hingga perlakuan iradiasi pada dosis 150 Gy meskipun jumlah telur yang diletakkan lebih sedikit dari pada kontrol. Tampak bahwa kemampuan peneluran S. frigidus dipengaruhi oleh perlakuan iradiasi, semakin tinggi dosis iradiasi semakin tertunda waktu awal

Tabel 3. Keberhasilan perkembangan pupa Sternochetus frigidus menjadi imago yang diiradiasi dan fertilisasinya

\begin{tabular}{lcccc}
\hline & \multicolumn{3}{c}{ Perkembangan yang dimulai dari fase pupa } \\
\cline { 2 - 4 } $\begin{array}{l}\text { Dosis } \\
\text { Gy) }\end{array}$ & $\begin{array}{c}\text { Jumlah dewasa hidup } \\
\text { normal }\end{array}$ & $\begin{array}{c}\text { Jumlah dewasa hidup } \\
\text { tidak normal }\end{array}$ & Jumlah telur & Jumlah larva \\
\cline { 2 - 5 } & \multicolumn{3}{c}{ Rataan \pm SE } \\
\hline Kontrol & $1,33 \pm 0,58 \mathrm{a}$ & $0,67 \pm 1,15 \mathrm{a}$ & $0,00 \pm 0,00 \mathrm{a}$ & $0,00 \pm 0,00 \mathrm{a}$ \\
50 & $0,33 \pm 0,58 \mathrm{ab}$ & $2,33 \pm 0,58 \mathrm{ab}$ & $0,00 \pm 0,00 \mathrm{a}$ & $0,00 \pm 0,00 \mathrm{a}$ \\
100 & $1,00 \pm 0,00 \mathrm{ab}$ & $5,33 \pm 0,58 \mathrm{~b}$ & $0,00 \pm 0,00 \mathrm{a}$ & $0,00 \pm 0,00 \mathrm{a}$ \\
150 & $0,33 \pm 0,58 \mathrm{ab}$ & $3,00 \pm 1,00 \mathrm{ab}$ & $0,00 \pm 0,00 \mathrm{a}$ & $0,00 \pm 0,00 \mathrm{a}$ \\
200 & $0,00 \pm 0,00 \mathrm{~b}$ & $2,33 \pm 0,58 \mathrm{ab}$ & $0,00 \pm 0,00 \mathrm{a}$ & $0,00 \pm 0,00 \mathrm{a}$ \\
300 & $0,00 \pm 0,00 \mathrm{~b}$ & $4,33 \pm 2,08 \mathrm{~b}$ & $0,00 \pm 0,00 \mathrm{a}$ & $0,00 \pm 0,00 \mathrm{a}$ \\
400 & $0,00 \pm 0,00 \mathrm{~b}$ & $3,67 \pm 1,53 \mathrm{ab}$ & $0,00 \pm 0,00 \mathrm{a}$ & $0,00 \pm 0,00 \mathrm{a}$ \\
\hline \multicolumn{4}{c}{ Percobaan II } & $8,68 \pm 1,53 \mathrm{a}$ \\
\hline Kontrol & $2,67 \pm 0,58 \mathrm{a}$ & $2,00 \pm 1,00 \mathrm{a}$ & $33,33 \pm 12,01 \mathrm{a}$ & $1,67 \pm 0,58 \mathrm{~b}$ \\
50 & $2,33 \pm 0,58 \mathrm{a}$ & $2,33 \pm 0,58 \mathrm{ab}$ & $7,67 \pm 4,04 \mathrm{~b}$ & $0,00 \pm 0,00 \mathrm{~b}$ \\
100 & $6,33 \pm 2,08 \mathrm{~b}$ & $5,33 \pm 0,58 \mathrm{~b}$ & $0,00 \pm 0,00 \mathrm{~b}$ & $0,00 \pm 0,00 \mathrm{~b}$ \\
150 & $3,33 \pm 0,57 \mathrm{a}$ & $3,00 \pm 0,00 \mathrm{c}$ & $0,00 \pm 0,00 \mathrm{~b}$ & $0,00 \pm 0,00 \mathrm{~b}$ \\
300 & $2,33 \pm 0,58 \mathrm{a}$ & $2,33 \pm 0,58 \mathrm{ad}$ & $0,00 \pm 0,00 \mathrm{~b}$ & $0,00 \pm 0,00 \mathrm{~b}$ \\
400 & $4,33 \pm 2,08 \mathrm{ab}$ & $4,33 \pm 2,08 \mathrm{bc}$ & $0,00 \pm 0,00 \mathrm{~b}$ & $0,00 \pm 0,00 \mathrm{~b}$ \\
\hline
\end{tabular}

Rata-rata yang diikuti oleh huruf yang sama pada kolom yang sama menunjukkan tidak berbeda nyata berdasarkan uji Tukey pada $\alpha=0,05$. 
peneluran dan semakin berkurang jumlahnya (Gambar 5). Pada kedua percobaan, iradiasi sinar gamma pada dosis $\geq 200$ Gy menyebabkan imago betina $S$. frigidus tidak mampu menghasilkan telur (Tabel 5).

Kemampuan imago untuk bertelur dipengaruhi oleh dosis iradiasi sinar gamma. Rataan jumlah telur paling banyak ditemui pada dosis 0 (kontrol) pada percobaan pertama dan kedua berturut-turut, yaitu 521 dan 887 butir telur, yang selanjutnya diikuti pada dosis 50 sampai 400 Gy. Selanjutnya, kemampuan telur untuk menetas menjadi larva juga berbeda tiap dosis perlakuan. Rataan jumlah larva paling banyak ditemui pada kontrol untuk percobaan pertama dan kedua berturut-turut, yaitu 169 dan 113 individu, yang selanjutnya diikuti dengan dosis 50 sampai 400 Gy. Kemampuan imago menghasilkan telur masih dapat terjadi di dosis $150 \mathrm{~Gy}$, sedangkan perkembangan telur menjadi larva di dosis 100 Gy (Tabel 5).

\section{PEMBAHASAN}

Nilai faktor keseragaman dosis (FKD) merupakan rasio keseragaman dosis serap maksimum dan minimum yang diterima sampel. Rasio tersebut dikategorikan baik jika mendekati

Tabel 4. Pengaruh iradiasi sinar gamma terhadap jumlah gigitan, persentase hidup normal, dan kematian imago

\begin{tabular}{lcccc}
\hline \multirow{2}{*}{$\begin{array}{l}\text { Dosis } \\
\text { (Gy) }\end{array}$} & $\begin{array}{c}\text { Jumlah } \\
\text { pasang } \\
\text { kumbang }\end{array}$ & $\begin{array}{c}\text { Jumlah gigitan pada } \\
\text { pakan }\end{array}$ & Persentase hidup normal & $\begin{array}{c}\text { Persentase kematian } \\
\text { (bulan ke-3) }\end{array}$ \\
\cline { 2 - 5 } & \multicolumn{5}{c}{ Rataan \pm SE } & Rataan \pm SE & Rataan \pm SE \\
\hline Kontrol & 30 & $11,0 \pm 0,0 \mathrm{a}$ & $100,0 \pm 0,0 \mathrm{a}$ & $20,0 \pm 5,0 \mathrm{a}$ \\
50 & 30 & $7,0 \pm 1,0 \mathrm{~b}$ & $100,0 \pm 0,0 \mathrm{a}$ & $25,0 \pm 5,0 \mathrm{a}$ \\
100 & 30 & $7,3 \pm 1,5 \mathrm{~b}$ & $93,3 \pm 5,7 \mathrm{a}$ & $51,7 \pm 17,6 \mathrm{bc}$ \\
150 & 30 & $4,0 \pm 1,0 \mathrm{c}$ & $85,0 \pm 5,0 \mathrm{a}$ & $63,3 \pm 0,1 \mathrm{~cd}$ \\
200 & 30 & $3,8 \pm 1,5 \mathrm{c}$ & $61,7 \pm 18,9 \mathrm{~b}$ & $76,7 \pm 15,3 \mathrm{de}$ \\
300 & 30 & $2,0 \pm 0,5 \mathrm{~cd}$ & $33,3 \pm 7,6 \mathrm{c}$ & $86,7 \pm 7,6 \mathrm{e}$ \\
400 & 30 & $0,7 \pm 0,5 \mathrm{~d}$ & $13,3 \pm 2,9 \mathrm{c}$ & $96,7 \pm 5,8 \mathrm{e}$ \\
\hline \multicolumn{5}{c}{ Percobaan II } \\
\hline Kontrol & 30 & $9,3 \pm 1,5 \mathrm{ab}$ & $100,0 \pm 0,0 \mathrm{a}$ & $13,3 \pm 0,1 \mathrm{a}$ \\
50 & 30 & $10,3 \pm 0,6 \mathrm{a}$ & $88,3 \pm 10,4 \mathrm{a}$ & $33,3 \pm 0,1 \mathrm{ab}$ \\
100 & 30 & $2,7 \pm 2,3 \mathrm{c}$ & $86,7 \pm 14,4 \mathrm{a}$ & $61,7 \pm 0,2 \mathrm{abc}$ \\
150 & 30 & $5,3 \pm 1,1 \mathrm{abc}$ & $81,7 \pm 2,9 \mathrm{a}$ & $73,3 \pm 0,1 \mathrm{abc}$ \\
200 & 30 & $4,3 \pm 2,5 \mathrm{bc}$ & $85,0 \pm 8,7 \mathrm{a}$ & $93,3 \pm 0,2 \mathrm{bc}$ \\
300 & 30 & $2,7 \pm 2,5 \mathrm{c}$ & $75,0 \pm 20,0 \mathrm{a}$ & $100,0 \pm 0,3 \mathrm{bc}$ \\
400 & 30 & $3,0 \pm 2,7 \mathrm{c}$ & $68,3 \pm 2,9 \mathrm{a}$ & $96,7 \pm 0,2 \mathrm{c}$ \\
\hline
\end{tabular}

Angka pada kolom yang sama yang diikuti oleh huruf yang sama menunjukkan tidak berbeda nyata berdasarkan uji Tukey pada $\alpha=0,05$.

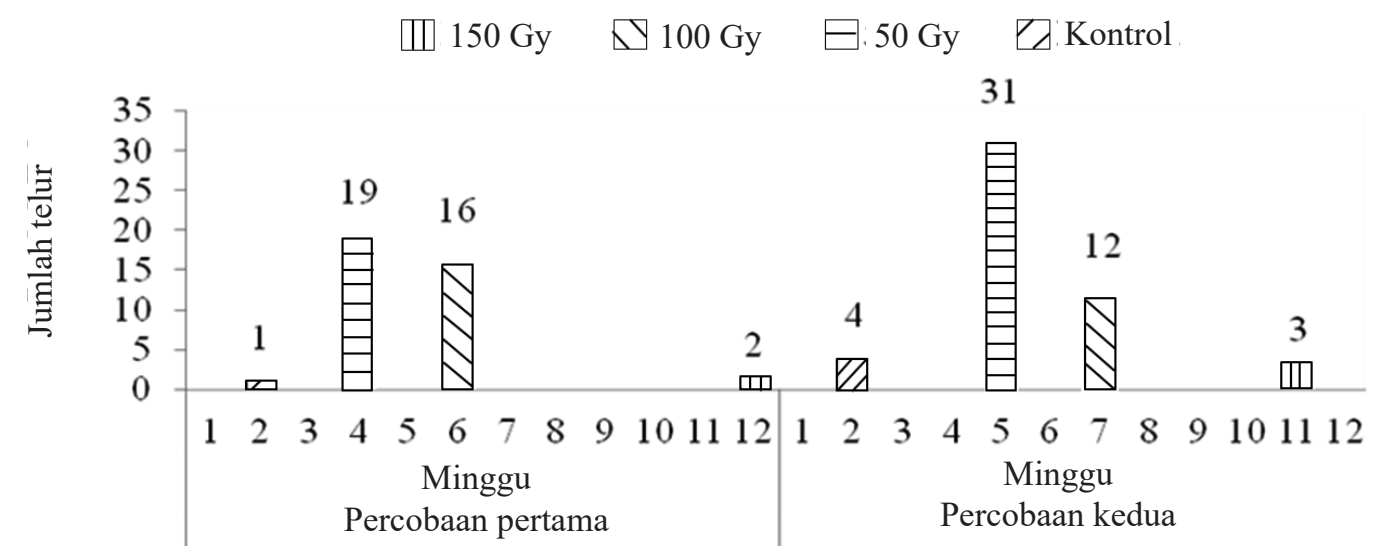

Gambar 5. Waktu peneluran awal oleh serangga Sternochetus frigidus pada berbagai dosis perlakuan sinar gamma. 
Tabel 5. Pengaruh iradiasi sinar gamma terhadap sterilitas imago Sternochetus frigidus

\begin{tabular}{lcccccc}
\hline \multirow{2}{*}{ Dosis (Gy) } & \multirow{2}{*}{$\begin{array}{c}\text { Jumlah } \\
\text { pasang } \\
\text { imago }\end{array}$} & \multicolumn{2}{c}{ Percobaan I } & Percobaan II & & \multicolumn{2}{c}{ Jumlah larva \pm SE (individu) } \\
\cline { 3 - 4 } \cline { 6 - 7 } & & Rataan \pm SE & Rataan \pm SE & & Rataan \pm SE & Rataan \pm SE \\
\hline 0 & 30 & $521,0 \pm 265 \mathrm{a}$ & $887,0 \pm 119,9 \mathrm{a}$ & & $169,0 \pm 54,0 \mathrm{a}$ & $113,3 \pm 9,9 \mathrm{a}$ \\
50 & 30 & $234,0 \pm 29,1 \mathrm{~b}$ & $53,3 \pm 62,4 \mathrm{~b}$ & & $25,7 \pm 17,2 \mathrm{~b}$ & $9,3 \pm 5,7 \mathrm{~b}$ \\
100 & 30 & $48,0 \pm 45,9 \mathrm{~b}$ & $5,0 \pm 7,0 \mathrm{~b}$ & & $2,3 \pm 2,1 \mathrm{~b}$ & $3,7 \pm 6,4 \mathrm{~b}$ \\
150 & 30 & $6,0 \pm 1,7 \mathrm{~b}$ & $2,3 \pm 2,0 \mathrm{~b}$ & & $0 \pm 0,0 \mathrm{~b}$ & $0 \pm 0,0 \mathrm{~b}$ \\
200 & 30 & $0 \pm 0,0 \mathrm{~b}$ & $0 \pm 0,0 \mathrm{~b}$ & & $0 \pm 0,0 \mathrm{~b}$ & $0 \pm 0,0 \mathrm{~b}$ \\
300 & 30 & $0 \pm 0,0 \mathrm{~b}$ & $0 \pm 0,0 \mathrm{~b}$ & & $0 \pm 0,0 \mathrm{~b}$ & $0 \pm 0,0 \mathrm{~b}$ \\
400 & 30 & $0 \pm 0,0 \mathrm{~b}$ & $0 \pm 0,0 \mathrm{~b}$ & & $0 \pm 0,0 \mathrm{~b}$ & $0 \pm 0,0 \mathrm{~b}$ \\
\hline
\end{tabular}

Angka pada kolom yang sama yang diikuti oleh huruf yang sama menunjukkan tidak berbeda nyata berdasarkan uji Tukey pada $\alpha=0,05$.

angka 1 (IAEA 2002). Faktor ketidakseragaman dosis dapat terjadi apabila kemasan kardus yang digunakan semakin besar dimensi, densitasnya, dan tidak seragam ukuran kemasan satu dengan lainnya. Lama waktu pemaparan iradiasi dipengaruhi oleh dosis, ukuran, dan densitas bahan yang diradiasi. Iradiasi pada kuini dalam kotak kemasan $1 \mathrm{~kg}$ pada dosis terkecil 50 Gy lebih cepat, yaitu 3, 12 menit, sedangkan pada dosis 400 Gy diperlukan waktu 25, 42 menit dengan densitas sekitar $0,25 \mathrm{~g} / \mathrm{cm}^{3}$ (Tabel 2). Umumnya iradiator sinar gamma untuk keperluan sterilisasi dan fitosanitari didesain agar memenuhi rasio keseragaman.

Serangga $S$. frigidus tidak ditemukan pada buah kuini di daerah Bekasi, Jawa Barat (Syahputra et al. 2019). Untuk itu, dalam penelitian ini sumber buah yang terinfestasi dikumpulkan dari Sumatera. Informasi ini juga penting untuk pemantauan serangan S. frigidus di lapangan.

Pemaparan iradiasi sinar gamma pada fase pupa dan serangga imago dapat memengaruhi perkembangan kedua fase tersebut. Tingkat perkembangan fase pupa lebih rendah dibandingkan fase dewasa. Hal ini disebabkan oleh adanya perbedaan daya radiotoleran pada kedua fase. Tingkat perkembangan fase dewasa lebih tinggi dibandingkan dengan fase pupa saat terpapar sinar gamma. Fase serangga yang radiotoleran sinar gamma paling tinggi berturutturut diperoleh pada fase dewasa, pupa, dan larva (Hallman et al. 2010). Helinski et al. (2006) menyatakan bahwa tingkat kemampuan imago dalam menghasilkan telur dari fase pupa lebih rendah dibandingkan dengan imago yang tidak terpapar iradiasi sinar gamma. Demikian juga Obra et al. (2013) menyatakan bahwa fase yang paling tahan terhadap iradiasi sinar gamma adalah fase imago. Pada serangga yang terpapar radiasi sinar gamma, penurunan kemampuan hidup imago serangga jantan dan betina $S$. frigidus dipengaruhi oleh dosis iradiasi, seperti yang dinyatakan oleh Obra et al. (2017) bahwa semakin tinggi dosis iradiasi maka akan semakin menurunkan daya hidup imago.

Percobaan pertama memberikan hasil yang berbeda dengan percobaan kedua baik dalam hal jumlah gigitan pada pakan maupun jumlah serangga hidup normal (Tabel 3). Hal ini dapat dipengaruhi oleh waktu pengamatan setelah perlakuan. Pada percobaan pertama tingkat pengaruh iradiasi tampak semakin tinggi yang ditunjukkan oleh jumlah serangga hidup normal yang semakin rendah dibandingkan dengan percobaan kedua.

Kondisi serangga hidup normal memiliki ciri yang sewajarnya tanpa adanya getaran pada bagian dari antena dan tungkai. Perlakuan iradiasi sinar gamma untuk serangga sudah dilakukan pada stadia telur, larva, pupa, dan beberapa imago sudah diuji di antaranya dari kelompok Ordo Coleoptera (Obra et al. 2013; Obra et al. 2014). Pada percobaan kedua, hidup normal serangga uji menunjukkan tidak berpengaruh nyata pada seluruh dosis perlakuan dibandingkan dengan percobaan pertama. Kondisi hidup normal imago pada percobaan pertama menunjukkan semakin menurun dengan bertambahnya dosis radiasi sinar gamma dibandingkan percobaan kedua. Hal ini kemungkinan karena sinar gamma yang 
dipaparkan belum memberikan pengaruh pada kondisi hidup imago pada rentang waktu empat minggu. Hal lain kemungkinan karena faktor umur imago yang berbeda, semakin bertambah umur imago akan mempengaruhi kondisi hidup imago setelah terkena radiasi sinar gamma.

Pemaparan radiasi sinar gamma memberikan pola pengaruh yang sama pada kematian imago, semakin tinggi dosis perlakuan memberikan tingkat kematian imago yang makin meningkat (Tabel 4). Klassen et al. (1969) menyatakan bahwa iradiasi sinar gamma dapat memengaruhi proses fisologi mahluk hidup.

Perlakuan iradiasi terhadap masing-masing fase serangga menunjukkan bahwa hanya fase pupa yang dapat berkembang ke fase imago. Imago yang berhasil berkembang dari fase pupa yang diiradiasi masih mampu bertelur bahkan beberapa berhasil menjadi larva, tetapi jumlahnya lebih rendah dari pada kontrol. Obra et al. (2013) menyatakan bahwa pupa yang diradiasi masih dapat menghasilkan telur dan larva hingga dosis 50 Gy. Ini mungkin menjadi informasi pertama bahwa $S$. frigidus dapat berkembang menjadi imago dari pupa di luar inangnya. Lorenzana \& Obra (2013) menyatakan bahwa proses hidup serangga $S$. frigidus hanya berada di dalam buah.

Perlakuan iradiasi sinar gamma dapat memengaruhi kondisi fisik serangga. Hasil iradiasi dengan kontrol dari stadia pupa menunjukkan adanya perbedaan perkembangan fisik imago. Imago dari pupa yang tidak diiradiasi tidak mengalami perubahan fisik atau normal, sedangkan yang diiradiasi menunjukkan adanya ketidaknormalan pada posisi sayap bagian elitera yang tidak tertutup normal (Gambar 4). Obra et al. (2013) menyatakan bahwa perlakuan iradiasi sinar gamma pada dosis 25 Gy hingga 300 Gy dapat memengaruhi pertumbuhan fase larva, pupa, dan imago $S$. frigidus bahkan imago dapat mengalami abnormalitas fisik pada elitranya. Sebagaimana disampaikan oleh Carpenter \& Iivstone (1971), perlakuan dengan iradiasi pada stadia pupa serangga dapat mempengaruhi perkembangan kondisi stadia selanjutnya, yaitu perkembangan fisik imago yang tidak normal. Lebih jauh lagi Obra et al. (2013) juga menyatakan bahwa iradiasi sinar gamma dapat memengaruhi aktivitas makan serangga sehingga dapat mempercepat kematian.
Perlakuan iradiasi sinar gamma memengaruhi kemampuan bertahan hidup imago S. frigidus, seperti terjadinya penurunan jumlah telur yang diletakkan dan aktivitas makan walaupun serangga $S$. frigidus berada di dalam buah kuini. Obra et al. (2013) melaporkan bahwa perlakuan iradiasi dosis 100 Gy menunjukkan hanya satu imago betina yang bertelur dan tidak terdapat telur yang berhasil menetas menjadi larva, sedangkan pada dosis 150 Gy tidak ada telur yang diletakkan. Dengan demikian, telur S. frigidus dari hasil imago yang diiradiasi sinar gamma pada dosis 100 Gy masih dapat menetas menjadi larva dengan persentase keberhasilan menetas yang lebih rendah dari perlakuan iradiasi gamma pada dosis $50 \mathrm{~Gy}$. Sinar gamma mampu menembus jaringan buah kuini. Iradiasi sinar gamma menghasilkan radikal bebas yang reaktif dan bereaksi dengan molekul di dalam sel. Reaksi yang terjadi mengacaukan proses-proses biokimia di dalam sel sehingga mengganggu keseimbangan sel. Keadaan ini menyebabkan molekul lain di dalam sel tidak dapat berproses secara normal (Klassen et al. 1969).

Perlakuan sinar gamma dapat mematikan serangga $S$. frigidus, semakin tinggi dosis perlakuan maka memberikan persentase kematian yang lebih tinggi bahkan hingga 100\% kematian walaupun hingga lebih dari 4 bulan. De Jesus \& Gabo (2000) melaporkan bahwa siklus hidup $S$. frigidus dapat mencapai 10 bulan.

Davich \& Lindquist (1962) melaporkan bahwa iradiasi sinar gamma pada dosis $\geq 50$ Gy menurunkan lama hidup dan reproduksi kumbang buah kapas Anthonomus grandis Boheman. Sementara itu, iradiasi pada dosis 100-150 Gy menyebabkan serangga jantan menjadi steril dan berakibat kematian. Iradiasi menyebabkan kematian kumbang tersebut akibat gangguan terhadap proses fisiologi sel dalam produksi dan pelepasan enzim pencernaan ke dalam saluran pencernaan serangga (Riemann \& Flint 1967). Lebih lanjut, iradiasi dosis 100-150 Gy dapat mengakibatkan pengaruh tambahan dari sterilitas, seperti menghambat penetasan telur serta mempersingkat lama hidup imago jantan dan betina (Klassen et al. 1969). Telur yang sudah tua di dalam serangga betina berada pada kondisi premeiosis dan biasanya berkembang menjadi metafase I sampai proses peletakan telur untuk melengkapi 
meiosis dengan menghasilkan pronukleus 1 dan 3 badan polar. Menurut Robinson (2005), telur matang di dalam tubuh serangga betina lebih tahan terhadap sinar gelombang radio daripada tipe sel yang lebih muda termasuk oogensis maupun oogonia. Iradiasi sinar gamma dapat menyebabkan penundaan kesuburan serangga betina.

Iradiasi sinar gamma tidak berpengaruh negatif terhadap kualitas mangga, tidak meninggalkan residu, dan tidak menyebabkan makanan berbahaya untuk kesehatan manusia (data tidak ditampilkan), serta sebagai alternatif perlakuan karantina yang aman bagi konsumen dalam mengeradikasi hama tanaman (WHO 1994; Hallman 2016). Dari hasil perlakuan iradiasi bahwa di dosis 400 Gy buah kuini tidak mengalami perubahan fisik pada kulit dan daging buah.

\section{KESIMPULAN}

Iradiasi sinar gamma pada dosis 200 Gy dapat mensterilkan imago $S$. frigidus, sedangkan pada dosis 50, 100, dan 150 Gy serangga masih dapat bertelur dan dosis 100 Gy telur masih dapat berkembang menjadi larva. Sementara itu, pupa yang diperlakukan pada dosis 50 Gy masih mampu bertelur dan membentuk larva, sedangkan dosis di atas 100 Gy tidak dapat menghasilkan telur.

\section{UCAPAN TERIMA KASIH}

Penulis mengucapkan terima kasih kepada Badan Karantina Pertanian yang telah memberikan dana tahun anggaran 2017 dan Pusat Aplikasi Isotop dan Radiasi (PAIR-BATAN) yang telah menyediakan fasilitas sebagai iradiator sinar gamma dalam mendukung penelitian ini.

\section{DAFTAR PUSTAKA}

ASTM F1991-99. 2016 Standard Test Method for Performance of Chinese (Wok) Ranges, ASTM International, West Conshohocken, PA, 2016, www.astm.org

[BPS] Badan Pusat Statistik. 2016. Statistik Tanaman Buah-buahan dan Sayuran Tahunan. Jakarta: BPS.
[BPS] Badan Pusat Statistik. 2016. Statistik Tanaman Buah-buahan dan Sayuran Tahunan. Jakarta:BPS. Carpenter RL, Livstone EM. 1971. Evidence for nonthermal effects of microwave radiation: abnormal development of irradiated insect pupae. IEEE Transactions on Microwave Theory and Techniques 19:173-178. doi: https://doi. org/10.1109/TMTT.1968.1127480.

Davich TB, Lindquist DA. 1962. Exploratory studies on gamma radiation for thesterilizaton of the boll weevil. Journal of Economic Entomology 55:164-167. doi: https://doi.org/10.1093/ jee/55.2.164.

[DAWR] Department of Agriculture and Water Resources - Biosecurity. 2015. Final report for the non-regulated analysis of existing policy for fresh mango fruits from Indonesia, Thailand and Vietnam. Tersedia pada: http://www.agriculture. gov.au/import/goods/food [diunduh 2016 Desember 21].

De Jesus LRA. 2008. Reproductive potential, feeding and oviposition preferences of the mango pulp weevil, Sternochetus frigidus (Fabr.) (Coleoptera: Curculionidae), on 'Carabao' mango. Philippine Agricultural Scientist 91:29-35.

De Jesus LRA, Gabo RR. 2000. Life history and host range of the mango pulp weevil, Sternochetus frigidus (Fabr.) in Palawan, Philippines. Philippine Agricultural Scientist 83:145-150.

[Ditjen] Direktorat Jenderal Hortikultura. 2016. Laporan kinerja direktorat jenderal hortikultura. Jakarta. Tersedia di: http://sakip.pertanian.go.id/ admin/data2/LAKIN\%20HORTI\%202016\%20 PDF\%20GABUNG.pdf. [diunduh 2016 Desember 21].

Hallman GJ, Levang-Brilz NM, Zettler JL, Windborne IC. 2010. Factors affecting ionizingradiation phytosanitary treatments, and implications forresearch and generic treatments. Journal of Economic Entomology 103:1950-1963.

Hallman GJ. 2016. Generic phytosanitary irradiation treatment for "true weevils" (Coleoptera: Curculionidae) infesting fresh commodities. Florida Entomologist 99:197-201. doi: https:// doi.org/10.1603/EC10228.

Helinski MEH, Parker AG, Knols BGJ. 2006. Radiation-induced sterility for pupal and adult stages of the malaria mosquito Anopheles arabiensis. Malaria Journal 5:1-10. doi: https:// doi.org/10.1186/1475-2875-5-41.

[IAEA] International Atomic Energy Agency. 2002. Irradiation as a Phytosanitary Treatment of Food and Agricultural Commodities. Vienna: IAEA. 
[ICGFI] International Consultative Group on Food Irradiation. 1986. Task Force Meeting on Irradiation as a Quarantine Treatment. Vienna: IAEA.

[IPPC] International Plant Protection Convention. 2009. ISPM \#5, Glossary of Phytosanitary Terms. Rome: FAO

Klassen W, Norland JP, Briggs RW. 1969. Sterilizaton of boll weevils with combinatons of chemosterilants and x-rays, gamma rays, thermal neutrons, or fast neutrons. Journal of Economic Entomology 62:1204-1216. doi: https://doi. org/10.1093/jee/62.5.1024a.

Lorenzana LRJ, Obra GB. 2013. Mass rearing technique for pulp weevil, Sternochetus frigidus (Fabr.) (Coleoptera: Curculionidae). Journal ISSAAS 19:75-81.

Miyauchi Y, Perry C. 1999. Marketing fresh fruit to Japanese consumers: Exploring issues for Australian exporters. European Journal of Marketing, 33:196-205. doi: https://doi. org/10.1108/03090569910249238.

Obra GB, Resilva SS, Lorenzana LRJ. 2013. Irradiation as a potential phytosanitary treatment for the mango pulp weevil Sternochetus frigidus (Fabr.) (Coleoptera: Curculionidae) in Philippine super mango. Philippine Agricultural Scientist 96:172-178.

Obra GB, Resilva SS, Follett PA, Lorenzana LRJ. 2014. Large-scale confirmatory tests of a phytosanitary irradiation treatment against Sternochetus frigidus (Coleoptera: Curculionidae) in Philippine mango. Journal of Economic Entomology 107:161-165. doi: https://doi.org/10.1603/EC13316.
Obra GB, Resilva SS, Lorenzana LRJ. 2017. Effect of gamma iradiation on egg hatchability, adult survival and longevity of the mango pulp weevil, Sternochetus frigidus (Fabr.). Philippine Journal of Science 146:299-303.

Poonchaisri S, Chaowalit S. 2008. Identification of weevils in genus Sternochetus. Di dalam: Report of the Meeting: the Fifth Consultation Meeting on Cooperation in Plant Quarantine Activities at the Thailand and Malaysia Borders (Chiang Mai, 22-24 Desember 2008). Chiang Mai Province, Thailand.

Riemann JG, Flint HM. 1967. Irradiaton effects on midguts and testes of theadult boll weevil, Anthonomus grandis, determined by histological andshielding experiments. Annals of the Entomological Society of America 60:298-308. doi: https://doi.org/10.1093/aesa/60.2.298.

Robinson AS. 2005. Genetic basis of the sterile insect technique. Di dalam: Dyck VA, Hendrichs J, Robinson AS (Eds.), Sterile Insect Technique: Principles and Practice in Area-Wide Integrated Pest Management. hlm. 95-114. Dordrecht: Springer. doi: https://doi.org/10.1007/1-40204051-2_4.

Syahputra A, Ahad M, Abdurakhman, Hidayat J. 2019. Abstrak. Identification, distribution, and testing the level of Sternochetus (Sternochetus sp, Coleoptera: Curculionidae) attack and the host status using no-choice test. Jurnal Hama dan Penyakit Tumbuhan Tropika 1:149-157.

[WHO] World Health Organization. 1994. Safety and Nutritional Adequacy of Irradiated Food. Geneva: WHO. 